REPORTS OF MORPHOLOGY
$\begin{gathered}\text { Official Journal of the Scientific Society of Anatomists, } \\ \text { Histologists, Embryologists and Topographic Anatomists } \\ \text { of Ukraine } \\ \text { journal homepage: https://morphology-journal.com }\end{gathered}$

\title{
Comparative analysis of the effects of various detoxification solutions on the structure of the kidneys in experimental burn disease in rats
}

\author{
Cherkasov V.G. ${ }^{1}$, Lachtadyr T.V. ${ }^{1}$, Fedoniuk L. Ya. ${ }^{2}$, Shypitsyna O.V. ${ }^{3}$ \\ ${ }^{1}$ O.O. Bogomolets National Medical University, Kiev, Ukraine \\ 2 Ivan Horbachevsky Ternopil State Medical University, Ternopil, Ukraine \\ ${ }^{3}$ National Pirogov Memorial Medical University, Vinnytsya, Ukraine
}

\author{
ARTICLE INFO \\ Received: 20 February, 2019 \\ Accepted: 19 March, 2019 \\ UDC: $611.611: 57.012: 57.08: 616.5-$ \\ 001.17
}

\section{CORRESPONDING AUTHOR}

e-mail: anatomi@ukr.net Cherkasov V.G.
The use of existing infusion solutions, as well as the development, scientific substantiation and implementation of the latest nephroprotective detoxification solutions, remain an urgent problem for combustiologists. The aim of this work is to compare the effects of various detoxification solutions $(0.9 \% \mathrm{NaCl}$ solution and complex colloid-hyperosmolar solutions - lactoprotein with sorbitol and the newly developed HAES-LX-5\% solution) on the kidney structure in experimental burn disease in rats. The experimental rats were divided into seven groups (fifteen animals each): the first group was intact rats; the second, third and fourth groups were rats without reproduction of experimental burn disease, which had a separate intravenous infusion of $0.9 \% \mathrm{NaCl}$ solution, lactoprotein with sorbitol and HAES-LX-5\% at a dose of $10 \mathrm{ml} / \mathrm{kg}$; the fifth, sixth and seventh groups were rats with experimental burn disease (by causing burn injury of the skin with an area of $21-23 \%$ of the body surface), which under the same scheme had an intravenous infusion of the investigated solutions. All studies and the removal of rats from the experiment were performed under deep thiopental intraperitoneal anesthesia. Histological preparations of the renal cortex of the rat were stained with hematoxylin-eosin and examined on an Olympus BX51 microscope. Using ultramicrotome LKB-3 (Sweden) obtained semi-thin sections which were stained with toluidine blue and methylene blue - Azur II; and ultrathin sections were counterstained with uranyl acetate and lead citrate according to Reynolds and examined using a PEM-125K electron microscope. Morphometric measurements (estimation of the area of the vascular glomeruli, the area of the urinary lumen of the capsule of the renal corpuscles; the area of the renal tubules of the nephrons and the area of their lumens, the area of the renal corpuscles, the area of cytoplasm and nuclei of epithelial cells of tubules, and also their nuclear-cytoplasmic ratio) was carried out using the VideoTest-5.0, KAARA Image Base and Microsoft Excel on a personal computer. Statistical analysis of the obtained quantitative indicators was performed using the IBM SPSS v. 22.0. for Windows. Functionally different cells of nephrons have been found to die by necrosis, apoptosis and anoikis when infused with detoxification solutions during the development of burn disease; in epithelial cells of nephron tubules, mitophagy and mitoptosis occur. Mitoptosis in epithelial cells of rat tubules of nephrons with experimental burn skin injury is carried out in two ways related to: 1) destruction of the outer mitochondrial membrane; 2) preservation of the outer mitochondrial membrane and involvement of autophagic (mitophagic) mechanisms to release the cell from degraded mitochondrial material. In the first case, the mitochondria first condense, after which its matrix swells and the fragmentation of the cristae occurs due to the destruction of the junction of the cristae. Finally, the outer mitochondrial membrane breaks and the remnants of the cristae (in the form of vesicles) go into the cytoplasm. In the second case, the mitochondria condense, vesicular fragmentation of the cristae occurs, but the rupture of the outer mitochondrial membrane does not occur and the mitochondria are absorbed by the autophagosome (or transformed into the autophagosome). Next is the merger of autophagosomes with lysosomes and the formation of autophagolysosomes, which, under 
the conditions of effective digestion of the contents, are transformed into vacuoles. The latter are emptied by exocytosis and ensure the release of cells from degraded material. Only lactoprotein with sorbitol has a membrane-plastic effect on the strengthening (enhancement of structuring) of the mitochondrial membrane in part of the mitochondria of epithelial cells of nephron tubules, which is ultrastructurally manifested by an increase in the electron density and thickness of all components of the mitochondria. The maximum membrane effect of lactoprotein with sorbitol against mitochondria manifests itself fourteen days after the experimental burn skin injury and gradually (after twenty-one and thirty days) disappears, which is correlated with an improvement in the overall clinical condition and an improvement in the structural changes in the kidney of animals with burn disease. There is every reason to believe that increased structuration of mitochondria is a preventer of the spread of mitoptosis and mitophagy, the excess of which can lead to cell death.

Keywords: burn disease, detoxification solutions, reactive and destructive changes of the kidneys.

\section{Introduction}

Severe and large skin burns cause structural and functional pathological changes in all organs and systems of burned persons, which initiates the development of burn disease [14], a disease that has become increasingly widespread in recent years $[9,26]$.

According to researchers [14], burn disease is a disease that involves a set of clinical, morphological and biochemical, metabolic and other related disorders in all organs and systems. One of the leading factors in these disorders is the direct burn of the local destruction of large tissue arrays, which becomes a source of endotoxins and a factor in the formation and distribution of various biologically active substances. A powerful source of endotoxins and other biologically active substances are also tissue components of organs that were not initially subjected to thermal alteration but were in a state of discirculating hypoxia and histotoxic ischemia for some time.

It should be noted that thermal damage and gradual endogenous intoxication cause imbalance of water-salt homeostasis, increased permeability and destruction of the hemocapillary wall. In the treatment of burn disease (caused by severe burn injuries), the main goal of intravenous infusion therapy is to ensure an adequate level of tissue perfusion at the initial stages of the burn disease; normalization of tissue metabolism; prevention of severe toxic, hypoxic and reperfusion damage of cells and tissues [21, 23, 25].

Therefore, for a long time, scientific justification for the use of existing infusion solutions for reducing the level of toxins in the body and for normalizing the function of the kidneys, aimed at maintaining water-salt metabolism, remains relevant for combustiologists $[3,5,6,8,15,17,18,25]$, as well as the development and implementation of the latest nephroprotective detoxification solutions.

The aim of this work is to compare the effects of various detoxification solutions $(0.9 \% \mathrm{NaCl}$ solution and complex colloid-hyperosmolar solutions - lactoprotein with sorbitol and the newly developed HAES-LX-5 \% solution) on the kidney structure in experimental burn disease in rats.

\section{Materials and methods}

Comparative analysis of structural changes in rat kidney after experimental skin burn under the conditions of intravenous infusion, namely: isotonic sodium chloride solution $(0.9 \% \mathrm{NaCl}$ solution) and colloid-hyperosmolar solutions (lactoprotein with sorbitol and HAES-LX-5 \%) was performed on 105 white male rats weighing 155-160 grams.

Detention in the vivarium and all manipulations with rats were carried out in full compliance with the provisions of the "General Ethical Principles for Animal Experiments", approved by the First National Congress on Bioethics (Kyiv, 2001), with strict adherence to the recommendations of the "European Convention for the Protection of Vertebrate Animals Used for Experimental and Other Scientific Purposes" (Concil of Europe, Strasburg, 1986).

The experimental rats were divided into seven groups (fifteen animals each): the first group was intact rats; the second, third and fourth groups were rats without reproduction of experimental burn disease, which had a separate intravenous infusion of $0.9 \% \mathrm{NaCl}$ solution, lactoprotein with sorbitol and HAES-LX-5 \% at a dose of $10 \mathrm{ml} / \mathrm{kg}$; the fifth, sixth and seventh groups were rats with experimental burn disease, which under the same scheme was administered an intravenous infusion of the test solutions.

For the simulation of burn disease, an experimental skin burn was performed by pressing four heated copper plates (two plates on each side, an area of each $13.86 \mathrm{~cm} 2$ ) which were previously kept for six minutes in water at a constant temperature of $100^{\circ} \mathrm{C}$. To determine the extent of damage in the experimental burn injury, the severity index was used, which considers the parameters of the area and depth of burns, as well as the total skin area of the burn. The calculation data show that the experimental burn injury covered 21-23\% of the animal's body surface, which is sufficient for the formation of grade II-III burns, the development of moderateseverity burn shock, and the initiation of burn disease.

The infusion of solutions at a dose of $10 \mathrm{ml} / \mathrm{kg}$ was carried out for five minutes in a caudal vena cava after its introduction of the catheter in aseptic conditions through the femoral vein. The course of infusion therapy lasted for seven days (the first intravenous infusion was performed one hour after the experimental burn injury, the subsequent injections were carried out once a day).

The experimental burn injury, catheterization of the main vessels was performed under anesthesia caused by 
intraperitoneal injection of propofol at a dose of $60 \mathrm{mg} / \mathrm{kg}$.

Material was removed from rats for morphological examination of the kidneys under deep thiopental intraperitoneal anesthesia fourteen, 21 and 30 days after the experimental burn skin injury. For histological examination, the obtained biopsies were treated according to the conventional procedure and stained with hematoxylin-eosin. Histological preparations of the rat renal cortex were examined on an Olympus BX51 microscope.

When receiving material for electron microscopic examination of rats under deep thiopental intraperitoneal anesthesia, the opening of the abdominal cavity was performed. The rat kidney biopsies were crushed into small blocks and fixed in glutaraldehyde solution. After standard wiring, the material was poured into an araldite mixture with epon.

Semi-thin and ultra-thin sections were made using an ultramicrotome LKB-3 (Sweden). The resulting semi-thin sections were stained with toluidine blue and methylene blue - azure II. Ultrathin sections were contrasted on copper support meshes with uranyl acetate and lead citrate according to Reynolds. Electron microscopic examination was performed using a PEM-125K electron microscope.

To objectify comparative analysis of the course of reactive and destructive processes in the renal cortex of burned rats, a morphometric study was performed. Evaluated: areas of vascular glomeruli, areas of urinary lumen of the capsule of the renal corpuscles; the renal tubule area of nephrons and the area of their lumen, the area of the renal corpuscles, the area of cytoplasm and nuclei of epithelial tubular cells, as well as their nuclear-cytoplasmic ratio.

Images from histological specimens stained with hematoxylin-eosin were taken to a computer monitor using a MICROmedSEOSCAN microscope and using a Vision CCD Camera. Morphometric measurements were performed using VideoTest-5.0, KAAPA Image Base, and Microsoft Excel on a personal computer.

Statistical analysis of the obtained quantitative indicators was performed using the IBM SPSS v. 22.0. for Windows. The values of the arithmetic mean $(\mathrm{M})$, the error of the arithmetic mean $(\mathrm{m})$ were calculated for all investigated parameters and the standard deviation $(\sigma)$ was determined. The significance of the difference of values between the independent quantitative values was calculated under the conditions of normal distribution (the estimate of the type of distribution was verified by the $X^{2}$ - Pearson criterion) by the Student's t-test (using the Bonferroni correction for more than two groups), and in other cases the Mann-Whitney $U$ test was used. Comparison of qualitative features was performed using criterion $x^{2}$. The differences at $p<0.05$ were considered significant.

\section{Results}

Studies have shown the unconditional positive benefits of intravenous infusion of colloid-hyperosmolar solutions over infusion of $0.9 \% \mathrm{NaCl}$ solution, which is further substantiated by statistical analysis of the data obtained from morphometric measurements. There are also differences in the influence on the structure of the renal cortex of burned rats of lactoprotein with sorbitol and HAES-LX$5 \%$.

The study showed that experimental burn skin injury and the resulting burn disease lead to significant structural changes in the components of the kidney after fourteen, twenty-one and thirty days (in the stages of late toxemia and septicotoxemia of burn disease, manifestations of which were manifested by timely infusion therapy). In temporal terms, the process of destruction and structural restructuring in the renal cortex of experimental burned rats in the investigated time of the experiment does not fade, but is only modified.

Fourteen days (Fig. 1,2) after experimental burn injury of the skin with the introduction of $0.9 \% \mathrm{NaCl}$ solution, the destruction of hemocapillaries, edema and hemorrhage in the interstitium of the renal cortex occurs (this process is mosaic and widespread). Twenty-one days and thirty days after, structural changes deepen and become focal, limited in nature: the necrosis and hemorrhage areas become larger, but their number decreases. A characteristic feature of these terms of burn disease is the involvement in the process of structural damage to the immune component, which is evidenced by the appearance of foci of lymphocytic and plasmacytic infiltrates in the renal cortex. The efficacy of recorded lymphocytic and plasmacytic infiltration of the renal cortex is questionable, because infiltrate plasmocytes are substantially structurally altered and subject to apoptotic transformation.

Summarizing the results of the study of the structural changes of the renal cortex of rats with skin burns, which were injected with $0.9 \% \mathrm{NaCl}$ solution, we can conclude that its infusion does not cause pronounced nephroprotective effects, and the structures of the renal cortex are characterized by the presence of morphological changes in the composition of the glomerular and tubular apparatus. Positive substantially compensatory-adaptive reactions include structural features of the presence of the functional potential of podocytes due to the preservation of podocytes and stabilization of the thickness of the basement membrane. The reactive manifestations can also be attributed to the process of eliminating damaged mitochondria by mitoptosis, but the dualism of this process should be emphasized. Mitoptosis is able to inhibit apoptosis, but its spread can lead to macroautophagy and necrotic cell death.

The use of infusion monotherapy alone with the effects of severe skin burns with $0.9 \% \mathrm{NaCl}$ solution has a certain positive effect on the body of burned rats (by reducing the level of endogenous intoxication, which is reflected in the mortality rate recorded in the study). At the same time, the results of the study indicate the benefits of using combined colloid-hyperosmolar infusion solutions, endowed with nephroprotective properties, which improves the regenerative capacity of kidney cells. 


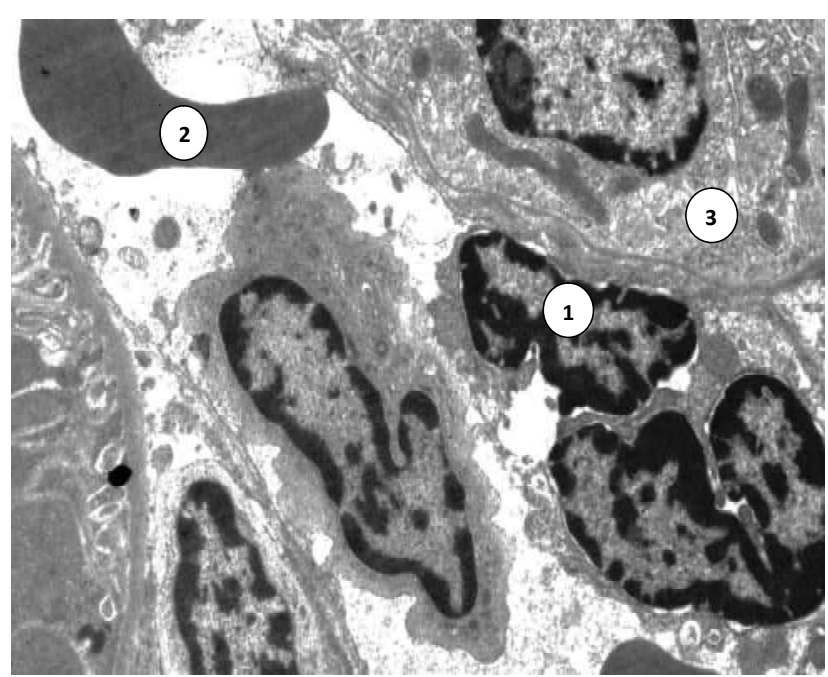

Fig. 1. Destruction of the wall of the peritubular hemocapillary, edema and hemorrhage in the interstitium of the renal cortex of the rat 14 days after the experimental burn injury with the introduction of $0.9 \% \mathrm{NaCl}$ solution. 1 - nucleus of destroyed endothelial cell; 2 - erythrocyte in swollen interstitial space; 3 - basal pole of the epithelial cell of the distal tubule of the nephron. Electronic micrograph. x10000.

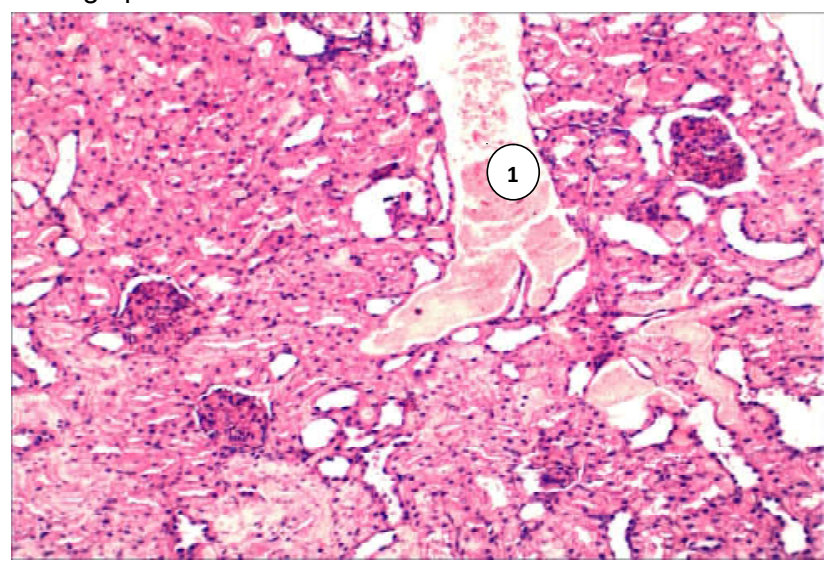

Fig. 2. Combination of sharp expansion of peritubular venules with the formation of sludge erythrocyte conglomerates (1) and with partial destruction of the vascular wall in the renal cortex of the rat 14 days after the experimental burn injury under the condition of $0.9 \% \mathrm{NaCl}$ solution. Photomicrograph. Hematoxylin-eosin staining. $\mathrm{x} 100$.

We have found that due to hyperosmolarity, lactoprotein with sorbitol and HAES-LX-5\% provide the transfer of excess fluid (resulting from the inflammatory response to burn injury) from the intracellular sector to the vascular bed. It optimizes the hemomicrocirculation and stabilizes the perfusion in the kidneys, which is morphologically determined and histophysiologically justified in the analysis of the results of this study.

Histological, electron microscopic and morphometric studies indicate that (unlike $0.9 \% \mathrm{NaCl}$ solution) lactoprotein with sorbitol and HAES-LX-5\% exert a cytoprotective effect on the structure of the rat kidney with experimental burn injury, thus revealing nephroprotective properties. The analysis of morphometric data indicates statistically significant $(p<0.001)$ changes in different size of renal corpuscles, which can be divided into two groups: I - large (hypertrophied) renal corpuscles; II - small (atrophied) renal corpuscles. The size and structural organization of these renal corpuscles indicate the different degree of their functional load and the potential for the implementation of the filtration function. Fourteen days after the experimental burn skin injury, their average area under infusion of $0.9 \% \mathrm{NaCl}$ solution was $8453 \pm 203 \mu \mathrm{m}^{2}$ and $4687 \pm 128 \mu \mathrm{m}^{2}$, respectively. Comparison of the range of oscillations of the sizes of the average area of the large and small renal corpuscles at different periods of the experiment after the experimental burn skin injury (after fourteen, twenty-one and thirty days) shows a significant increase of the average area of the large renal corpuscles $(p<0.001)$, the size of the average area of the vascular glomerulus $(p<0.01)$ and mean area of the urinary space of the kidney capsule of renal corpuscles $(p<0.01)$ under the conditions of infusion of lactoprotein with sorbitol and HAESLX-5 \%, which indicate positive (compared to $0.9 \% \mathrm{NaCl}$ solution) positive effect of colloid-hyperosmolar solutions on the course of reactive processes in kidney cells of burned rats.

The influence of lactoprotein with sorbitol on the structural changes of the kidneys is reflected in the statistically significant difference of the majority of the investigated morphometric parameters characterizing the functional abilities of the filtration and reabsorption apparatus of the kidneys of burned rats of this experimental group, from the similar ones that characterize the state of the renal cortex of burned rats administered $0.9 \% \mathrm{NaCl}$ solution.

Only lactoprotein with sorbitol has a membrane-plastic effect on the strengthening (enhancement of structuring) of the mitochondrial membrane in part of the mitochondria of epithelial cells of nephron tubules, which is ultrastructurally manifested by an increase in the electron density and thickness of all components of the mitochondria. The maximum membranoplastic effect of lactoprotein with sorbitol on mitochondria manifests itself fourteen days after the experimental burn skin injury and gradually (twenty-one and thirty days later) disappears, which correlates with an improvement in overall clinical status and dynamics disease. There is every reason to believe that increased structuration of mitochondria is a preventer of the spread of mitoptosis and mitophagy, the excess of which can lead to cell death. This effect is not a consequence of the direct action of lactoprotein with sorbitol, but is a consequence of the action of lactoprotein with sorbitol under conditions of the development of burn disease (Fig. 3) and is absent under normal conditions (Fig. 4).

Summarizing the results of our study of structural changes in the renal cortex of the rat with experimental burn skin injury, which was administered lactoprotein with sorbitol, we can conclude that intravenous infusion of this solution leads to inhibition of nephrocyte alteration. The kidneys in rats of this experimental group have less pronounced 


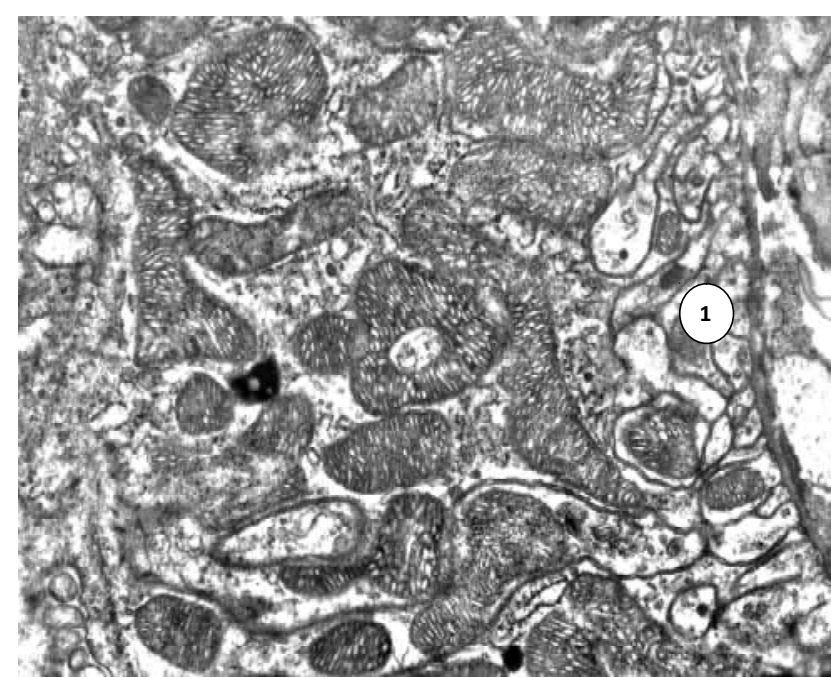

Fig. 3. The accumulation of over-structured mitochondria in the cytoplasm of the epithelial cell of the proximal tubule in the renal cortex of the rat 14 days after the experimental burn injury under the conditions of the introduction of lactoprotein with sorbitol. 1 basal striations. Electronic micrograph. $\mathbf{x} 40000$.

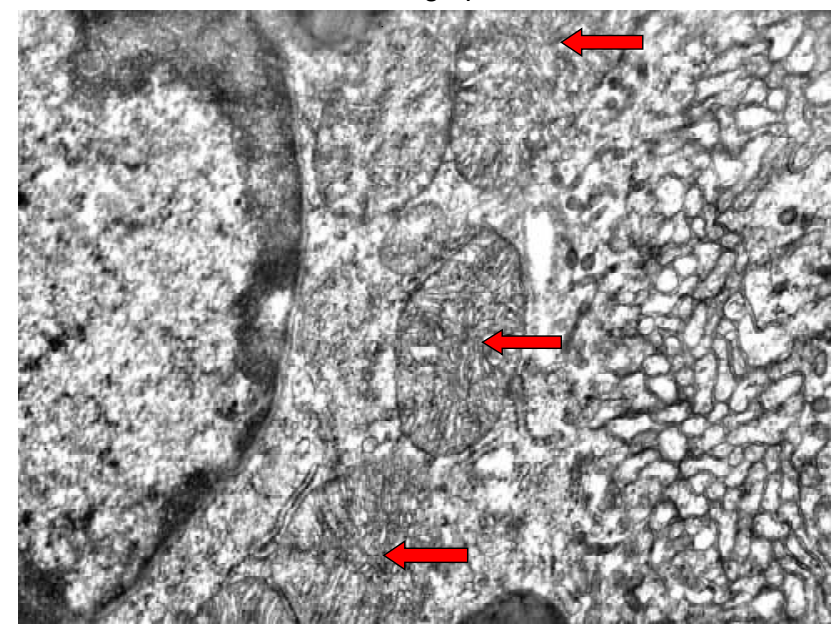

Fig. 4. Ultrastructural structure of mitochondria (marked by arrows) located in the cytoplasm of the epithelial cell of the proximal tubule in the renal cortex of the rat without experimental burn skin injury (normal). Electronic micrograph. $\mathbf{x} 40000$.

changes in the structure and, accordingly, more preserved functionality of the cells of nephrons, compared with those in the burned rats who were administered $0.9 \% \mathrm{NaCl}$ solution.

The intensification of the regenerative processes in the vascular component of the nephron tubules and renal corpuscles leads to an overall improvement in microcirculation and, consequently, a normalization of their functions. The protective effect covers not only the organelles of the epithelial cells of the tubules, but extends to the organelles of podocytes and endothelial cells of the hemocapillaries of the vascular glomerulus and to the common basement membrane, which inhibits the integrity of the filtration barrier.

Our studies indicate that a number of interrelated pathological consequences of severe experimental burn skin injury are capable of producing renal damage at the cellular level, and the use of infusion of colloid-hyperosmolar combined solution of lactoprotein with sorbitol, which intentionally stimulates organelles protein-synthesizing apparatus and corrects the metabolic substrate of nephron cells, significantly limiting the gradient morphofunctional changes in the renal cortex in burned rats.

Like lactoprotein with sorbitol, the influence of HAES-LX$5 \%$ under the development of burn disease manifests itself in nephroprotective action. Just as in the case of lactoprotein infusion with sorbitol, the structural features of HAES-LX-5 $\%$ influence are reflected in the statistically significant difference of the majority of the studied morphometric parameters characterizing the state of the filtration and reabsorption apparatus of rats with experimental burn skin trauma from similar, characterizing condition of the renal cortex of rats with experimental burn skin injury, which was administered $0.9 \% \mathrm{NaCl}$ solution.

Comparing the effects of the hyperosmolar solutions applied, it should be noted that the HAES-LX-5\% infusion provides a more harmonious effect on the renal cortex structure of the rat with experimental burn skin injury. The less pronounced manifestations of repair in this case are associated with a lower degree of destruction in the renal cortex of experimental animals, which is evidence of the nephroprotective properties of HAES-LX-5 \% (Fig. 5, 6).

We found that mitochondria of epithelial cells are the most active organelles under normal conditions and the most vulnerable ones under experimental burn skin injury. Increased functional load leads to an acceleration of the aging of their mitochondria, and in worse conditions - to the destruction of not only old but also defective mature and young mitochondria. Infusion of HAES-LX-5\% promotes the ordering and normalization of mitoptosis in epithelial cells of nephron tubules (see Fig. 6).

In rats with experimental burn skin injury, we observed mitoptosis of mitochondria of epithelial cells of nephron tubules. These mitochondria undergo microautophagic changes, including fusion of lysosomes with small damaged mitochondria or with small isolated fragments of branched mitochondria. Autophagolysosomes thus formed undergo a step-by-step transformation that can be defined in spatial dimension as the "base apical transformation sequence". In this sequence, the transformation of the autophagolysosome occurs in the direction from the electrondense autophagolysosome in the basal zone of the cytoplasm of the epithelial cell to the vacuole with electrontransparent content in the apical zone of the cytoplasm. Infusion of HAES-LX-5\% leads to the stabilization of this sequence, which reflects the protective properties of the solution relative to mitochondria.

Summarizing the results of the study of the structural changes in the renal cortex of the rat with experimental burn skin injury, which was injected with HAES-LX-5\%, we can conclude that the use of infusion of HAES-LX-5\% does not 


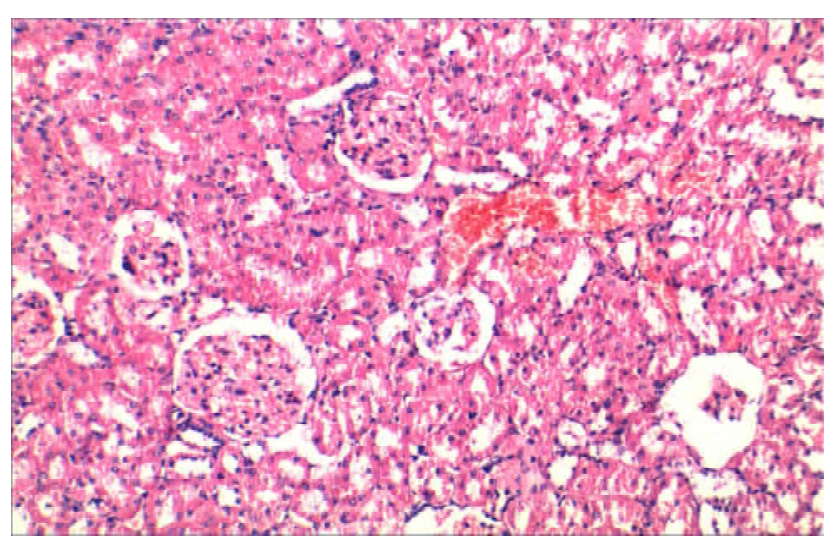

Fig. 5. The area of the renal cortex of the rat 14 days after the experimental burn injury with the introduction of HAES-LX-5\%. Photomicrograph. Hematoxylin-eosin staining. x100.

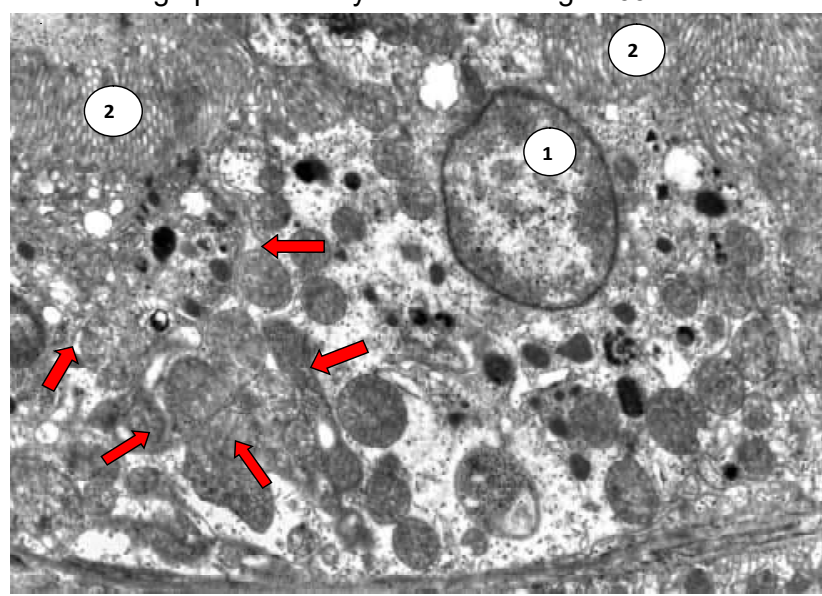

Fig. 6. Fusion of mitochondria, as well as their mitoptosis in the epithelial cell of the proximal tubule of nephron in the renal cortex of the rat 14 days after the experimental burn injury under the conditions of administration of HAES-LX-5\%. Arrowheads indicate zones of accumulation and confluence of mitochondria at different stages of their degradation. 1 - nucleus of epithelial cell; 2 - brush border. Electronic micrograph. $\times 25000$.

lead to a rapid complete restoration of the structural organization of the cells of the components of the nephron. However, the positive effect of such infusion therapy contributes to the activation of the organelles of the metabolic plan, improves hemomicrocirculation, and, accordingly, filtration and reabsorption functions. Such a normalizing effect makes it possible to recommend the use of a new colloidal-hyperosmolar HAES-LX-5 \% solution to ensure timely prevention and optimization of complex treatment of the harmful effects of severe burn injuries to the skin.

Some dynamics and selectivity of cell death in the renal cortex of burned experimental rats were revealed. We have found that under the infusion of $0.9 \% \mathrm{NaCl}$ solution, part of all cells of the rat renal cortex perish by necrosis; part of the epithelial cells of nephron tubules, epithelial cells of the parietal layer of the glomerular capsule, and endothelial cells of the blood microvessels perish by anoikis; some mesangiocytes die by apoptosis; in the epithelial cells of the tubules of the nephron there is a mitoptosis. The use of hyperosmolar colloidal solutions inhibits cell necrosis and modifies the remaining irreversible cell changes. It is worth noting that in all cases, the most resistant cells to the harmful effects of burn skin injury are podocytes. Podocytes maintain the structural integrity of the basement membrane and, as a result, stabilize the endothelial cells of the hemocapillaries of the vascular glomeruli, which exhibit a greater degree of resistance compared to the endothelial cells of the walls of the blood vessels of the peritubular mesh. The expression of reactive transformations of podocytes is the variability of the shape and size of cytotubules, cytopodia and soles of attachment of cytopodia. Their deformation modulations, together with changes in the basement membrane, are combined with an increase in the structure of the cytoskeleton elements (microfilaments and microtubules) located in the cytoplasm, which, in the aggregate, causes changes in the sizes and configurations of filtration slits and filtration diaphragms, thus changing.

We have noted that in some cells of the renal cortex of rat with experimental burn skin injury, structural changes of mitochondria occur by the mechanism of "out membrane mitoptosis". In this case, the mitochondria first condense, after which its matrix swells and the fragmentation of the cristae occurs due to the destruction of the junction of the cristae. Finally, the outer mitochondrial membrane breaks and the remnants of the cristae (in the form of vesicles) are released into the cytoplasm. As a rule, the mitochondria of the epithelial cells of the nephron tubules have an elongated rod-like shape, and when swollen, they fragment and become rounded (oval or spherical). However, in most epithelial cells of rat nephron tubules with experimental burn skin injury, a mixed type of mitoptosis has been reported. In this case, the mitochondria condense, there is a bubbling fragmentation of the cristae, but the rupture of the outer mitochondrial membrane does not occur and the mitochondria is absorbed by the autophagolysosome (or transformed into the autophagolysosome). Therefore, the final step in the transformation of the autophagolysosome is the formation of a vacuole with a transparent content (effective digestion of the content of the autophagolysosome), which by exocytosis releases its contents from the cell outside. Thus, mitoptosis can be accomplished both with and without the involvement of autophagic (mitophagic) mechanisms.

It is recognized that the mitophagy of damaged mitochondria of epithelial cells of nephron tubules inhibits the mitochondrial pathway of apoptosis activation. On the other hand, mitochondrial destruction and intense mitophagy contribute to cell death by accidental and unregulated or programmed necrosis involving lysosomal enzymes. Morphologically, both types of such cell death are accompanied by cell swelling, destruction of the plasmalemma, and release of cellular detritus into the extracellular space.

The stability of the mitochondrial shape in the basal 
divisions of the epithelial cells of the proximal tubules of rat nephrons with experimental burn skin injury is lost, the basal streakiness is deformed. In this case, the mitochondria are snug against each other. This process can be interpreted as the fusion of mitochondria and the formation of giant branched or annular mitochondria. It is not excluded that, in fact, we observe as giant branched mitochondria fragment and their fragments merge into their ends, forming mitochondria of the annular shape. That is, "mitochondrial fission and fusion" and "membrane tethering" [30] ocuur, result in the formation of separate and united "mitochondrial complexes".

In rats with experimental skin trauma administered $0.9 \% \mathrm{NaCl}$ solution, significant changes in the basal membrane in all components of the renal cortex were noted: loosening and local destruction of the basement membrane; loss of its characteristic structure and electron density. These structural shifts occur in the basement membrane of the walls of the blood microvessels, the parietal and visceral layers of the glomerular capsule, tubules of the nephrons. The dynamics of these transformations are in accordance with the severity of the destructive changes of cells for which the basement membrane is a subordinate extracellular matrix. In our worst-case scenario, the damaged cells merge into the corresponding spaces and the basement membrane becomes exposed.

Against the background of the described changes, the membrane-plastic effect of the infusion of lactoprotein with sorbitol, the structural expression of which is to stabilize the normal structure of the basement membrane, and also to the hyperplastic repair of the damaged basement membrane, which has the character of excess and uneven, is most clearly manifested. The latter, in particular, concerns the basal membrane in the wall of the tubules of the proximal divisions (at separate loci, the thickness of the basal membrane increases 3-6 times). Producer components of the basement membrane are adjacent cells, which show the structural features of activation of the protein-synthesizing apparatus of cells (first of all - the expansion of the tubules of the granular mesh, which are completely filled with finegrained content of average electron density).

The above-mentioned transformation of the basement membrane (the appearance of local defects and their inappropriate repair) reflects significant disorders of matrixcytoplasmic relationships in the kidney of rats with experimental burn skin injury. Loss of typical adhesive ties in the areas of the distorted basement membrane leads to autophagic (in the worst case, necrotic) or apoptotic (anoikis) changes of epithelial and endothelial cells and their attachment to the lumen of the hollow.

\section{Discussion}

In accordance with the above, the data obtained by us about autophagic, necrotic and apoptotic cell changes in the rat kidney with experimental burn skin injury indicate that selectively stimulated microautophagy (and, in particular, mitophagy) allows cells to survive when they have lost normal levels of extracellular matrix attachment for some time and then attach to it again. The latter is best manifested in the epithelial cells of the tubules of the proximal departments of the nephrons of rats with experimental burn skin injury, when the cytoplasmic processes (folds) of the basal striations are deformed, and the renewal of its typical architectonics (as a manifestation of the positive action of lactoprotein with sorbitol and HAES-LX-5\%) accompanied by the establishment of matrix-cytoplasmic contacts (establishment of a certain number of contacts and renewal or increase of the area of contact between the plasmalemma and the basement membrane).

Therefore, selective microautophagy in the form of mitophagy in the cells of the renal cortex of the rat with experimental burn skin injury is a manifestation of a compensatory-adaptive reaction whose balance has certain limits. If microautophagy is not adequately amplified, it leads to macroautophagy and may result in necrosis of the excessively vacuolated cell. If microautophagy is not adequately inhibited, it can lead to apoptotic changes in the cell. We found that the infusion solutions used lead to different variants of the destructive changes in the cells. Under the conditions of infusion of $0.9 \% \mathrm{NaCl}$ solution, mainly necrotic cell changes occur, which are accompanied by the development of interstitial edema, hemorrhage and lymphocytic infiltration. Under conditions of infusion of lactoprotein with sorbitol and HAES-LX-5\%, the spread of destructive changes in the renal cortex of burned rats is inhibited and substantially altered in both temporal and spatial dimensions. Intravenous infusion of applied colloidhyperosmolar solutions provides inhibition of cell necrosis, thus suppressing the intensity of the inflammatory response, changing the way of realization of mechanisms of mitoptosis (the main is "out membrane mitoptosis" or mitoptosis with wide involvement of autophagic localized processes) and contributes to the limited, local nature of autophagic and apoptotic changes. The effects of the components of the combined colloid-hyperosmolar solutions on the mitochondria require further study, but there is no doubt that the regulation of mitoptosis is a "switch" to prevent irreversible changes in the cells of the kidney of rats that cause disorders of renal detoxification function and are a consequence of the effects of burn disease factors in experimental burn skin injury.

Mitochondria have a leading role in cell function, not only by providing them various metabolic responses and energy production, but also by being the main site of reactive oxygen species formation and a key player in initiating cell death $[20,30]$. Therefore, mitochondrial dysfunction or damage can have serious consequences. Mitophagy (autophagic degradation of mitochondria) and mitoptosis (programmed destruction of mitochondria) are the processes by which cells are released from damaged mitochondria [2, 11, 13, $19,22,24,27]$. The effectiveness of these processes can be a factor that promotes or inhibits the development of various 
pathological conditions $[20,28]$.

We have found a specific lactoprotein with sorbitol membrane-stimulating ultrastructural effect in the development of burn disease, which is to enhance the structuring of the mitochondria of epithelial cells of nephron tubules, which can be regarded as strengthening the mitochondrial membrane. It is known [24] that, under conditions of intense functioning, under the influence of pathogenic factors, mitochondria are particularly vulnerable to mutations of their own DNA and protein misfolding in the tubules of the granular endoplasmic reticulum. Under normal conditions it is in the tubular cavity of the granular endoplasmic reticulum that the linear chains of amino acids are subject to post-translational modification and collapse, acquiring the necessary three-dimensional configuration. The answer to misfolded proteins is endoplasmic reticulum stress (endoplasmaticum stress or ER-stress), which usually involves the involvement of autophagic mechanisms for the disposal of misfolded proteins. Given that mitochondria are constructed from proteins encoded by both the nuclear and mitochondrial genomes, this adds even more complexity to the coordination of protein synthesis and import to the mitochondria of proteins encoded by the nuclear genome. In the study by Tinari A. et al. [27], it has been proved that several protein molecules can cause such reconstruction of mitochondrial membranes, leading to rupture of the mitochondrial membrane and to complete destruction of mitochondria. In view of the foregoing, we have noted that the strengthening of the mitochondrial membrane of mitochondria of epithelial cells is a regulator and a potential inhibitor of the spread of mitoptosis degradation.

In view of the above literature, the membrane-plastic effect of lactoprotein with sorbitol, aimed at enhancing the structuralization of the outer and inner mitochondrial septum, is a preventer of the spread of mitoptosis and mitophagy.

We have investigated and compared the effects of the influence of different infusion solutions on the structure of the renal cortex of burned rats: 1$)$ a typical crystalloid $(0.9 \%$ $\mathrm{NaCl}$ solution); 2) hyperosmolar colloidal solutions (lactoprotein with sorbitol and HAES-LX-5 \%). Structural changes of the filtration and reabsorption apparatus of the kidneys under these conditions differed in the nature and temporal parameters of the compensatory-adaptive reactions, as well as the degree of expressiveness of destructive and reparative processes (which is a manifestation of the protective and therapeutic effect of the solutions). The success of the positive effects of infusion solutions is largely determined not only by their osmolarity, but also by the physicochemical characteristics of their components (which was planned when designing these drugs by the developers).

The studies have shown the unconditional positive benefits of intravenous infusion of colloidal-hyperosmolar solutions over infusion of isotonic solution, which is $0.9 \%$ $\mathrm{NaCl}$ solution, which is confirmed and objectified by the data of the morphometric study. There are also differences in the influence on the structure of renal cortex of burned rats of lactoprotein with sorbitol and HAES-LX-5 \% groups.

It should be noted that the scientific literature continues to discuss the presence or absence of nephrotoxic effects of infusion colloid-electrolyte-hyperosmolar solutions based on hydroxyethyl starch of different generation $[1,4,7,10,12$, $16,21,23,29]$. The data obtained indicate the nephroprotective properties of a new (created on the basis of the hydroxyethyl starch of the third generation HES 130/ 0.4 ) balanced plasma substitute HAES-LX-5\%, which exerts a cytoprotective effect on the structure of the renal cortex of rats with experimental burn skin. These data are consistent with those of other researchers $[3,5,6,8,15,17,18]$ regarding the positive effects of HAES-LX- $5 \%$. All this gives reason to agree with the statement that colloid-hyperosmolar HAESLX-5 \% opens new opportunities in the treatment of burn disease. Prospects for further scientific research in this direction are to study the effects of different colloidhyperosmolar infusion solutions on the structure of the kidneys in various pathological conditions.

\section{Conclusions}

1. Comparative analysis of the effects of intravenous infusion of $0.9 \% \mathrm{NaCl}$ solution and complex colloidhyperosmolar solutions (lactoprotein with sorbitol and HAES-LX-5 \%) on the structure of the kidneys under experimental simulation of burn disease in rats (by causing burn injury of 21-23\% skin area of the body surface) indicates that each solution is characterized by the peculiarities of the action on the course of reactive and destructive processes in cells. Functionally different cells of nephrons under conditions of infusion of detoxification solutions in the development of burn disease die by necrosis, apoptosis and anoikis; in epithelial cells of nephron tubules, mitophagy and mitoptosis occur.

2. With intravenous infusion of detoxification solutions applied, the most resistant cells to the harmful effects of experimental burn skin injury are podocytes. Podocytes maintain the structural integrity of the basement membrane and, as a result, stabilize the endothelial cells of the hemocapillaries of the vascular glomeruli, which exhibit a greater degree of resistance than the endothelial cells of the vessel wall of the peritubular mesh. The expression of reactive transformations of podocytes is the variability of the shape and size of cytotubules, cytopodia and soles of attachment of cytopodia. Their deformation modulations, together with changes in the basement membrane, are combined with an increase in the structure of the cytoskeleton elements (microfilaments and microtubules) located in the cytoplasm, which, in the aggregate, causes changes in the sizes and configurations of filtration slits and filtration diaphragms, thus changing.

3. Mitoptosis in rat epithelial tubule cells with experimental burn skin injury is carried out in two ways related to: 1) destruction of the outer mitochondrial membrane; 2) preservation of the outer mitochondrial membrane and 
involvement of autophagic (mitophagic) mechanisms to release the cell from degraded mitochondrial material. In the first case, the mitochondria first condense, after which its matrix swells and the fragmentation of the cristae occurs due to the destruction of the junction of the cristae. Finally, the outer mitochondrial membrane breaks and the remnants of the cristae (in the form of vesicles) go into the cytoplasm. In the second case, the mitochondria condense, vesicular fragmentation of the cristae occurs, but the rupture of the outer mitochondrial membrane does not occur and the mitochondria are absorbed by the autophagosome (or transformed into the autophagosome). Next is the merger of autophagosomes with lysosomes and the formation of autophagolysosomes, which, under the conditions of effective digestion of the contents, are transformed into vacuoles. The latter are emptied by exocytosis and ensure the release of cells from degraded material.

4. Detoxification solutions used in the study give rise to different variants of reactive and destructive changes in the cells of renal cortex of rat with experimental burn skin injury. Under the conditions of intravenous infusion of $0.9 \% \mathrm{NaCl}$ solution, mainly necrotic changes of the cell occur, which are accompanied by the development of interstitial edema, hemorrhage and lymphocytic infiltration. Given the intravenous infusion of lactoprotein with sorbitol and HAES$L X-5 \%$, the spread of destructive changes in the renal cortex of rats with experimental burn skin injury is inhibited and substantially altered in both temporal and spatial dimensions. Intravenous infusion of applied colloidhyperosmolar solutions provides inhibition of cell necrosis, thus suppressing the inflammatory response and contributing to the limited, local nature of mitoptosis and apoptotic changes. Limited selective microautophagy in the form of mitophagy in the cells of the renal cortex of rat with experimental burn skin injury is a manifestation of a compensatory-adaptive reaction whose balance has certain limits. If microautophagy is not adequately propagated, it leads to macroautophagy and may result in necrosis of the excessively vacuolated cell. If the spread of microautophagy is not adequately restricted, it can lead to apoptotic changes in the cell.

5. In rats without experimental burn skin injury, unstimulated mitoptosis of individual mitochondria of nephron epithelial cells occurs. Such mitoptosis can be considered as a manifestation of basic control of mitochondrial homeostasis whose effectiveness is

\section{References}

[1] Bunn, F., Alderson, P., \& Hawkins, V. (2012). Colloid solutions for fluid resuscitation. Cochrane Database of Systematic Reviews, 7(6), 30-34. doi: 10.1002/14651858.CD001319.pub5

[2] Bhatia-Kiššová, I., \& Camougrand, N. (2010). Mitophagy in yeast: actors and physiological roles. FEMS yeast research, 10(8), 1023-1034. doi: 10.1111/j.1567-1364.2010.00659

[3] Cherkasov, E. V., Gunas, I. V., Chereshnyuk, I. L., \& Lysenko, D. A. (2012). Features of thymus cells cycle in rats after burn lesion of a skin. Ukrainian morphologycal almanac, 2(3), 109- determined by the timely removal of defective mitochondria. Widespread mitoptosis in epithelial cells of nephron tubules in rats with experimental burn skin injury is a form of response to the factors of burn disease and associated degradation of distorted mitochondria. Such mitoptosis is characteristic of burn disease and can be defined as stimulated. Its morphological differences are: 1) the appearance of a large number of structurally degraded condensed mitochondria; 2) increasing the number of autophagosomes; 3 ) the association of vacuoles with a transparent content with a large number of diverse heteromorphic autophagolysosomes with the content of varying degrees of structured material resulting from inefficient hydrolytic digestion.

6. In the cytoplasm of epithelial cells of the tubules of rats nephrons with experimental burn skin injury there is impaired stability of the shape, size and distribution of mitochondria. Against the background of mitoptosis, the formation of the mitochondrial network occurs, the formation of new (small) mitochondria by budding and separation. This process has a dualistic meaning: on the one hand, it is a manifestation of physiological adaptation to stressful conditions, which contributes to the resilience of mitochondria integrated into the network; on the other hand, it leads to deformation and complete disappearance in the basal part of the epithelial cells of the tubules of the nephrons of the basal striations, which under normal conditions arises due to the placement of the rod-like mitochondria perpendicularly ordered with respect to the basement membrane (such changes, by definition, significantly affect the reabsorption state).

7. Only lactoprotein with sorbitol has a membrane-plastic effect on the strengthening (enhancement of structuring) of the mitochondrial membrane in part of the mitochondria of epithelial cells of nephron tubules, ultrastructurally manifested by an increase in the electron density and thickness of all components of the mitochondrial membrane. The maximum membrane-plastic effect of lactoprotein with sorbitol against mitochondria manifests itself fourteen days after the experimental burn skin injury and gradually (after twenty-one and thirty days) disappears, which correlates with the improvement of the general clinical condition of the animal. There is every reason to believe that increased structuration of mitochondria is a preventer of the spread of mitoptosis and mitophagy, the excess of which can lead to cell death.

113.

[4] Davidson, I. J. (2006). Renal impact of fluid management with colloids: a comparative review. European journal of anaesthesiology, 23(9), 721-738. doi: 10.1017/ S0265021506000639

[5] Dzevulska, I. V., Cherkasov, E. V., Kovalchuk, O. I., Majewskyi, Y. G., Pastukhova, V. A., \& Kyselova, T. M. (2018). Influence of lactoproteinum solution with sorbitol on DNA content of cells of endocrine glands on the background of skin burn in 
rats. World of Medicine and Biology, 2(64), 33-39. doi: 10.26724/2079-8334-2018-2-64-33-39

[6] Gavryluk, A. O., Galunko, G. M., Chereshniuk, I. L., Tikholaz, V. O., Cherkasov, E. V., Dzevulska, I. V., \& Kovalchuk, O. I. (2018). Indicators cell cycle and DNA fragmentation in cells of small intestine mucosa 14, 21 and 30 days after skin burns on the background of preliminary infusion of solution lactoprotein with sorbitol or HAES-LX 5\%. World of Medicine and Biology, 1(63), 104-108. doi: 10.26724/2079-8334-2017-4-62-104-108

[7] Groeneveld, A. J., Navickis, R. J., \& Wilkes, M. M. (2011). Update on the comparative safety of colloids: a systematic review of clinical studies. Annals of surgery, 253(3), 470-483. doi: 10.1097/SLA.0b013e318202ff00

[8] Gunas, I. V., Guminskiy, Y. I., Ocheretna, N. P., Lysenko, D. A., Kovalchuk, O. I., Dzevulska, I. V., \& Cherkasov, E. V. (2018). Indicators cell cycle and DNA fragmentation of spleen cells in early terms after thermal burns of skin at the background of introduction $0.9 \% \mathrm{NaCl}$ solution. World of Medicine and Biology, 14(63), 116-120. doi: 10.26.724/2079-8334-2018-1-63-116120

[9] Haagsma, J. A., Graetz, N., Bolliger, I., Naghavi, M., Higashi, H., Mullany, E. C., ... \& Ameh, E. A. (2016). The global burden of injury: incidence, mortality, disability-adjusted life years and time trends from the Global Burden of Disease study 2013. Injury prevention, 22(1), 3-18. doi: 10.1136/injuryprev-2015041616

[10] Hartog, C. S., Kohl, M., \& Reinhart, K. (2011). A systematic review of third-generation hydroxyethyl starch (HES 130/0.4) in resuscitation: safety not adequately addressed. Anesthesia \& Analgesia, 112(3), 635-645. doi: 10.1213/ ANE.0b013e31820ad607

[11] Jangamreddy, J. R., \& Los, M. J. (2012). Mitoptosis, a novel mitochondrial death mechanism leading predominantly to activation of autophagy. Hepatitis monthly, 12(8), 6159-6163. doi: 10.5812/hepatmon.6159

[12] Kancir, A. S. P., Johansen, J. K., Ekeloef, N. P., \& Pedersen, E. B. (2015). The effect of $6 \%$ hydroxyethyl starch $130 / 0.4$ on renal function, arterial blood pressure, and vasoactive hormones during radical prostatectomy: a randomized controlled trial. Anesthesia \& Analgesia, 120(3), 608-618. doi: 10.1213/ANE.0000000000000596

[13] Kaushal, G. P., \& Shah, S. V. (2016). Autophagy in acute kidney injury. Kidney international, 89(4), 779-791. doi: 10.1016/j.kint.2015.11.021

[14] Keck, M., Herndon, D. H., Kamolz, L. P., Frey, M., \& Jeschke, M. G. (2009). Pathophysiology of burns. Wiener Medizinische Wochenschrift, 159(13-14), 327-336. doi: 10.1136/ bmj.328.7453.1427

[15] Kovalchuk, O., Cherkasov, E., Dzevulska, I., Kaminsky, R., Korsak, A., \& Sokurenko, L. (2017). Dynamics of morphological changes of rats' adenohypophysis in burn disease. Georgian medical news, (270), 104-108. PMID:28972493

[16] Kruer, R. M., \& Ensor, C. R. (2012). Colloids in the intensive care unit. American Journal of Health-System Pharmacy, 69(19), 1635-1642.

[17] Lakhtadyr, T. V. (2019). Structural changes of the rat kidney cortical substance in the long-term period after burn injury of the skin under conditions of HAES-LX-5\% infusion. Emergency Medicine, (5.100), 79-83. https://doi.org/10.22141/22240586.5.100.2019.177023

[18] Lachtadyr, T. V. (2017). Structural changes of rats' renal cortex in late period of skin burn injury under the conditions of the infusion by lactoprotein with sorbitol. Biomedical and Biosocial Anthropology, 28, 81-87.

[19] Lyamzaev, K. G., Nepryakhina, O. K., Saprunova, V. B., Bakeeva, L. E., Pletjushkina, O. Y., Chernyak, B. V., \& Skulachev, V. P. (2008). Novel mechanism of elimination of malfunctioning mitochondria (mitoptosis): formation of mitoptotic bodies and extrusion of mitochondrial material from the cell. Biochimica et biophysica acta (BBA)-Bioenergetics, 1777(78), 817-825. doi: 10.1016/j.bbabio.2008.03.027

[20] Mijaljica, D., Prescott, M., \& Devenish, R. J. (2010). Mitophagy and mitoptosis in disease processes. In Protein Misfolding and Cellular Stress in Disease and Aging (pp. 93-106). Humana Press, Totowa, NJ. doi: 10.1007/978-1-60761-7563_6

[21] Mohanan, M., Rajan, S., Kesavan, R., Mohamed, Z. U., Ramaiyar, S. K., \& Kumar, L. (2019). Evaluation of renal function with administration of $6 \%$ hydroxyethyl starch and $4 \%$ gelatin in major abdominal surgeries: A pilot study. Anesthesia, essays and researches, 13(2), 219-224. doi: 10.4103/aer.AER 25

[22] Muller, M., \& Reichert, A. S. (2011). Mitophagy, mitochondrial dynamics and the general stress response in yeast. Biochem Soc Trans, 39(5), 1514-1519. doi: 10.1042/BST0391514

[23] Mutter, T. C., Ruth, C. A., \& Dart, A. B. (2013). Hydroxyethyl starch (HES) versus other fluid therapies: effects on kidney function. Cochrane Database of Systematic Reviews, (7), CD007594. doi: 10.1002/14651858.CD007594.pub3

[24] Pickles, S., Vigié, P., \& Youle, R. J. (2018). Mitophagy and quality control mechanisms in mitochondrial maintenance. Current Biology, 28(4), R170-R185. doi: 10.1016/ j.cub.2018.01.004

[25] Serghiou, M. A., Niszczak, J., Parry, I., Li-Tsang, C. W. P., Van den Kerckhove, E., Smailes, S., \& Edgar, D. (2016). One world one burn rehabilitation standard. Burns, 42(5), 1047-1058. doi: 10.1016/j.burns.2016.04.002

[26] Smolle, C., Cambiaso-Daniel, J., Forbes, A. A., Wurzer, P., Hundeshagen, G., Branski, L. K., ... \& Kamolz, L. P. (2017). Recent trends in burn epidemiology worldwide: A systematic review. Burns, 43(2), 249-257. doi: 10.1016/ j.burns.2016.08.013

[27] Tinari, A., Garofalo, T., Sorice, M., Esposti, M. D., \& Malorni, W. (2007). Mitoptosis: different pathways for mitochondrial execution. Autophagy, 3(3), 282-284. doi: 10.4161/auto.3924

[28] Vigie, P., \& Camougrand, N. (2017). Role of mitophagy in the mitochondrial quality control. Medecine sciences: $M / S$, 33(3), 231-237. doi: 10.1051/medsci/20173303008

[29] Weiskopf, R. B. (2015). Lack of Nephrotoxicity of Hydroxyethyl Starch 130/0.4 When Used in Surgery. The Journal of the American Society of Anesthesiologists, 123(2), 482-483. doi: 10.1097/ALN.0000000000000719

[30] Zemirli, N., Morel, E., \& Molino, D. (2018). Mitochondrial dynamics in basal and stressful conditions. International journal of molecular sciences, 19(2), 564. doi: 10.3390/ijms 19020564

\section{ПОРІВНЯЛЬНИЙ АНАЛІЗ ВПЛИВІВ РІЗНИХ ДЕЗІНТОКСИКАЦІЙНИХ РОЗЧИНІВ НА СТРУКТУРУ НИРОК ПРИ} ЕКСПЕРИМЕНТАЛЬНІЙ ОПІКОВІЙ ХВОРОБІ У ЩУРІВ

Черкасов В.Г., Лахтадир Т.В., Федонюк Л.Я., Шипіцина О.В.

Застосування існуючих інфузійних розчинів, а також розробка, наукове обгрунтування і впровадження новітніх нефропротекторних дезінтоксикаційних розчинів залишається актуальною проблемою для комбустіологів. Метою роботи є порівняльний аналіз впливів різних дезінтоксикаційних розчинів (0,9 \% розчину NaCl та комплексних колоїдно-гіперосмолярних 
розчинів - лактопротеїну із сорбітолом та нещодавно розробленого розчину HAES-LX-5 \%) на структуру нирок при експериментальній опікові хворобі у щурів. Піддослідні щури були розподілені на сім груп (по 15 тварин у кожній): перша група - інтактні щури; друга, третя й четверта групи - щури без відтворення експериментальної опікової хвороби, котрим було здійснено окремо внутрішньовенну індрузію 0,9 \% розчину NaCl, лактопротеїну із сорбітолом та HAES-LX-5 \% у дозі 10 мл/ка; п'ята, шоста та сьома групи - щури з експериментальною опіковою хворобою (шляхом нанесення опікової травми шкіри площею 21-23 \% поверхні тіла), яким за аналогічною схемою було здійснено внутрішньовенну інфрузію досліджуваних розчинів. Усі дослідження і виведення щурів із експерименту проводили під глибоким тіопенталовим внутрішньочеревним наркозом. Гістологічні препарати кіркової речовини нирок щурів забарвлювали гематоксиліном-еозином і вивчали на мікроскопі Оlутриs BX51. Одержані за допомогою ультрамікротому LKB-3 (Швеція) напівтонкі зрізи забарвлювали толуїдиновим синім та метиленовим синім - азур II; а ультратонкі зрізи - контрастували уранілацетатом і цитратом свинцю за Рейнольдсом $i$ вивчали за допомогою електронного мікроскопа ПЕМ-125К. Морфометричні вимірювання (оцінка площі судинних клубочків, площі сечового просвіту капсули ниркових тілець; площі ниркових канальців нефронів та площі їхніх просвітів, площі ниркових тілець, площі цитоплазми та ядер епітеліальних клітин канальців, а також їх ядерно-цитоплазматичне співвідношення) здійснювали за допомогою програм BuдеоTест-5.0, КАAPA Image Base ma Microsoft Excel на персональному комп'ютері. Статистичний аналіз отриманих кількісних показників виконаний з використанням статистичного пакету IBM SPSS v. 22.0. for Windows. Встановлено, що фрункціонально різні клітини нефронів за умов інфузії дезінтоксикаційних розчинів при розвитку опікової хвороби гинуть шляхом некрозу, апоптозу та аноікісу; в епітеліальних клітинах канальців нефронів відбуваються мітофагія та мітоптоз. Мітоптоз в епітеліальних клітинах канальців нефрронів щурів 3 експериментальною опіковою травмою шкіри здійснюється двома шляхами що пов'язані з: 1) руйнацією зовнішньої мітохондріальної мембрани; 2) збереженням зовнішньої мітохондріальної мембрани та залученням аутофрагійних (мітофрагійних) механізмів для звільнення клітини від деградованого мітохондріального матеріала. У першому випадку мітохондрія спочатку конденсується, після чого відбувається набухання їі матриксу і фррагментація крист за рахунок руйнації з'єднань крист. Нарешті, зовнішня мітохондріальна мембрана розривається і залишки крист (у вигляді везикул) виходять у цитоплазму. У другому випадку мітохондрія конденсується, відбувається везикулярна фрагментація крист, але розриву зовнішньої мітохондріальної мембрани не відбувається і мітохондрія поглинається аутофагосомою (або перетворюється на аутофрагосому). Далі відбувається злиття аутофрагосом з лізосомами і утворення аутофраголізосом, які, за умов ефективного перетравлення вмісту, трансформуються у вакуолі. Останні випорожнюються шляхом екзоцитозу і забезпечують вивільнення клітини від деградованого матеріалу. Притаманна тільки лактопротеїну з сорбітолом мембранопластична дія щодо укріплення (посилення структуралізації) мітохондріальної оболонки у частини мітохондрій епітеліальних клітин канальців нефронів ультраструктурно проявляється підвищенням електронної щільності та товщини усіх складових мітохондріальної оболонки. Максимально зазначений мембранопластичний ефект дії лактопротеїну із сорбітолом щодо мітохондрій проявляється через 14 діб після експериментальної опікової травми шкіри і поступово (через 21 та через 30 діб) зникає, що корелює з поліпшенням загального клінічного стану і покращенням показників структурних змін нирок тварин з опіковою хворобою. $€$ усі підстави вважати, що посилення структуралізації мітохондрій $\epsilon$ запобіжником поширення мітоптозу та мітофрагії, надлишковий характер яких може призвести до клітинної загибелі.

Ключові слова: опікова хвороба, дезінтоксикаційні розчини, реактивні та деструктивні зміни нирок.

\section{СРАВНИТЕЛЬНЫЙ АНАЛИЗ ВЛИЯНИЙ РАЗНЫХ ДЕЗИНТОКСИКАЦИОННЫХ РАСТВОРОВ НА СТРУКТУРУ ПОЧЕК ПРИ ЭКСПЕРИМЕНТАЛЬНОЙ ОЖОГОВОЙ БОЛЕЗНИ У КРЫС \\ Черкасов В.Г., Лахтадыр Т.В., Федонюк Л.Я., Шипицына А.В.}

Применение существующих инфузионных растворов, а также разработка, научное обоснование и внедрение новейших нефропротекторных дезинтоксикационных растворов остается актуальной проблемой для комбустиологов. Целью работы является сравнительный анализ влияния различных дезинтоксикационных растворов (0,9 \% раствора $\mathrm{NaCl}$ и комплексных коллоидно-гиперосмолярных растворов - лактопротеина с сорбитолом и недавно разработанного раствора HAES-LX-5 \%) на структуру почек при экспериментальной ожоговой болезни у крыс. Испытуемые крысы были разделены на семь групп (по 15 животных в каждой): первая группа - интактные крысы; вторая, третья и четвертая группы - крысы без воспроизведения экспериментальной ожоговой болезни, которым была осуществлена отдельно инфузия 0,9 \% раствора $\mathrm{NaCl}$, лактопротеина с сорбитолом и HAES-LX-5 \% в дозе 10 мл/ке пятая; шестая и седьмая группы - крысы с экспериментальной ожоговой болезнью (путем нанесения ожоговой травмы кожи площадью 21-23 \% поверхности тела), которым по аналогичной схеме была осуществлена инфузия исследуемых растворов. Все исследования и вывод крыс из эксперимента проводили под глубоким тиопенталовым внутрибрюшным наркозом. Гистологические препараты коры почек крыс окрашивали гематоксилин-эозином и изучали на микроскопе Olympus BX51. Полученные с помощью ультрамикротома LKB-3 (Швеция) полутонкие срезы окрашивали толуидиновым синим и метиленовым синим - азур II; а ультратонкие срезы - контрастировали уранилацетатом и иитратом свинца по Рейнольдсу и изучали с помощью электронного микроскопа ПЭМ-125К. Морфометрические измерения (оценка площади сосудистых клубочков, площади мочевого просвета капсулы почечных телец; площади почечных канальцев нефронов и размеры их просветов, площади почечных телец, площади цитоплазмы и ядер эпителиальных клеток канальцев, а также их ядерно-цитоплазматического соотношения) осуществляли с помощью программ ВидеоTеcm-5.0, КАAPA Image Base u Microsoft Excel на персональном компьютере. Статистический анализ полученных количественных показателей выполнен с использованием статистического пакета IBM SPSS v. 22.0. for Windows. Установлено, что функционально разные клетки нефрронов при инфузии дезинтоксикационных растворов в условиях развития ожоговой болезни погибают путем некроза, апоптоза и аноикиса; в эпителиальных клетках канальцев нефронов происходят митофрагия и митоптоз. Митоптоз в эпителиальных клетках канальцев нефронов крыс с экспериментальной ожоговой травмой кожи осуществляется двумя путями, которые связаны с: I - разрушением наружной митохондриальной 
мембраны; II - сохранением наружной митохондриальной мембраны и присоединением аутофрагических (митофрагических) механизмов для освобождения клетки от деградированного митохондриального материала. В первом случае митохондрия сначала конденсируется, после чего происходит набухание ее матрикса и фррагментация крист за счет разрушения соединений крист. Наконец наружная митохондриальная мембрана разрывается и остатки крист (в виде везикул) выходят в цитоплазму. Во втором случае митохондрия конденсируется, происходит везикулярная фррагментация крист, но наружная митохондриальная мембрана сохраняет свою целостность и митохондрия поглощается аутофрагосомой (или превращается в аутофрагосому). Далее происходит слияние аутофрагосом с лизосомами и образование аутофраголизосом, которые, при условии эфрфективной переработки содержимого, трансформируются в вакуоли. Последние опорожняются путем экзоцитоза и обеспечивают освобождение клетки от деградированного материала. Присуще только лактопротеину с сорбитолом мембранопластическое действие, направленное на укрепление (усиленная структурализация) митохондриальной оболочки у части митохондрий эпителиальных клеток канальцев нефрона ультраструктурно проявляется повышением электронной плотности и толщины всех составляющих митохондриальной оболочки. Максимально мембранопластический эфрфрект действия лактопротеина с сорбитолом на митохондрии проявляется через 14 суток после экспериментальной ожоговой травмы кожи и постепенно (через 21 и через 30 суток) исчезает, что совпадает с улучшением общего клинического состояния и показателей структурных изменений в почках животных $c$ ожоговой болезнью. Есть все основания считать, что усиление структурализации митохондрий является предохранителем распространения митоптоза и митофрагии, чрезмерный характер которых может привести к клеточной гибели.

Ключевые слова: ожоговая болезнь, дезинтоксикационные растворы, реактивные и деструктивные изменения почек. 